\title{
The Tourism Disaster Vulnerability Framework: An application to tourism in small island destinations
}

\section{Quote as:}

Becken, S., Mahon, R., Rennie, H. \& Shakeela, A. (2014). The Tourism Disaster Vulnerability Framework: An application to tourism in small island destinations. Natural Hazards, 71(1), 955-972.

\begin{abstract}
Islands are known to be vulnerable to natural hazards, resulting in substantial risks for their tourism industries. To facilitate the systematic analysis of the underlying vulnerability drivers, a Tourism Disaster Vulnerability Framework was developed. The conceptual model then guided qualitative empirical research in three regions; the Caribbean, the South Pacific, and the Indian Ocean. The results from 73 interviews highlight common, as well as idiosyncratic, factors that shape the islands' hazardscapes and vulnerabilities. Key vulnerabilities included social, economic, political and environmental dimensions. Probably the most critical vulnerability driver is the lack of private sector investment in disaster risk reduction. This is inter-related with deficient planning processes, on-going demand for coastal products, lack of political will, and poor environmental conditions. Notwithstanding many barriers, some businesses and organisations engage proactively in addressing disaster risk. The paper's empirical evidence supports the validity of the framework and suggestions for further research are made.
\end{abstract}

Keywords: Tourism; Islands; Vulnerability; Natural Hazards; Framework 


\section{Introduction}

Over the last decade a number of disasters, including the impacts of tsunamis and cyclones have severely affected coastal tourist destinations. At the same time, tourism is continuing to grow globally with over one billion international arrivals in 2011 (UNWTO 2011).

Considering that a significant proportion of tourism occurs in potentially hazardous coastal zones, the need to better understand and manage tourism's vulnerability to natural hazards becomes evident. Island destinations are particularly vulnerable to natural disasters (Intergovernmental Panel on Climate Change (IPCC) 2007). For the case of the Pacific Island countries, for example, the World Bank (2006) reported 207 major natural disasters (157 of them windstorms) between 1950 and 2004. These affected about 3.5 million people in the region with an economic damage cost of over US\$6.5 billion. More recently, the decade of the 1990s is believed to have experienced disaster damage of about US $\$ 2.8$ billion in the South Pacific (World Bank 2006). In the Maldives, the combined direct and indirect costs to tourist resorts and loss of Government revenue from reductions in tourist arrivals as a result of the 2004 Indian Ocean tsunami has been estimated to be in excess of US\$300 million (Becken et al. 2011). Overlooking the importance of tourism in island hazard and vulnerability assessments has far reaching implications, including biased calculations of human casualties (Kellens et al. 2012).

Tourism is a key sector in most island states. For example, in the Caribbean tourism contributes $14.2 \%$ to the Caribbean's economy, generates one in every eight jobs, and accounts for $11.6 \%$ of total regional capital investment (WTTC 2011). In the Maldives, tourism contributes $30 \%$ to GDP and 63\% of total employment (Shakeela et al. 2012). Considering its economic importance, tourism operators should be actively involved in disaster risk reduction. In their case study on Northland, New Zealand, Becken and Hughey (2013) demonstrated how a closer relationship between tourism and emergency management 
poses mutual benefits. Their study demonstrated how disaster risk reduction in partnership with local emergency management organisations can be incorporated into a local Tourism Action Plan for destinations.

While investing into disaster preparedness and response is important for tourism (WTO 1998), it is equally important to address the causal factors that underlie disaster risks for tourism in island destinations. A coherent framework for a systematic analysis of tourism's vulnerability factors to natural hazards, however, is missing. The starting point of such a framework is to conceptualise a tourist destination as a human-environment system, in which social, economic and environmental factors interact (Becken, 2013; Hewitt, 1997; Turner et al. 2003). The framework should also distinguish hazards from vulnerabilities (i.e. building on Hewitt's (1997) conceptualisation of vulnerability as an alternative to the more technocratic natural hazards paradigm), and conceptualise opportunities for responding to these. The rationale is that the proactive policy making, planning and implementation of disaster risk reduction (DRR) measures are likely to reduce tourism's vulnerability and mitigate hazards (Comfort et al., 1999). This paper proposes a framework for an integrative analysis of tourism's vulnerability to natural hazards in island destinations. The framework will be 'populated' and evaluated for its validity and comprehensiveness, based on empirical data from island destinations in the Caribbean, the South Pacific and the Indian Ocean.

\section{Developing a framework}

\section{Hazards in island destinations}

While some research has investigated tourism's vulnerability to natural hazards (e.g. Becken 2012; Bird et al. 2010; Burby and Wagner 1996; Calgaro and Lloyd 2008; Hystad and Keller 2008; Mäntyniemi 2012), research on tourism vulnerability in an island context is sparse, despite considerable damage and loss observed in island destinations (Table 1), as reported 
for many decades even before the advent of mass tourism (see Lewis (1982) for Tonga). Becken (2005), Le Masson and Kelman (2011), and Meheux et al. (2007) document key hazards for island resorts, including the particular exposure of coastal zones to hurricanes, storm surges, coastal erosion and flooding due to runoff from inland mountains. Other hazards, such as water shortages are also well-known in many island destinations (Sheppard et al. 2005, in IPCC 2007), but have rarely been linked explicitly to tourism.

\section{TABLE 1 ABOUT HERE}

Climate change is likely to exacerbate the current hazard environment in islands and increase disaster risks (IPCC 2012; Lewsey et al. 2004), although the effect of climate change on some hazards (e.g. tropical cyclones, Knutson et al., 2010) remains uncertain. In addition, recent estimates of future sea level rise indicate that by 2100 global sea-level is likely to rise by at least twice the IPCC projections, and if future emissions are unmitigated it may well exceed one metre; the upper limit has been estimated as approximately two metres sea-level rise by 2100 (Climate Commission 2011). Such rises have severe implications, especially since they would materialise through the occurrence of storm surges and other high sea phenomena, much earlier than the end of the century. Overall, responses to climate change are now being framed with more emphasis on the present and the immediate future (Becken and Hay, 2012) rather than the long term. Climate change is also expected to influence 'external' factors, such as tourism demand, as a result of the changing attractiveness of different destinations (Hein et al. 2009) or in response to a particular disaster (Rittichainuwat 2008).

The existence and magnitude of hazards is shaped by geographic factors, such as islands' latitude, their elevation, their ecosystems and the tectonic make-up. An important factor determining the hazardscape of the Maldives, for example, is its low elevation with about 
$80 \%$ of the area being lower than one meter above sea level (Sovacool 2011). In addition to environmental hazard drivers of islands, human factors influence the extent and magnitude of hazards. For example, a small human resource base, limited human capacity, a small internal market and an extremely sensitive and competitive external market are some socio-economic factors that have been identified in the literature (Becken et al. 2011; Graci and Dodds 2010; Méheux et al. 2007). From a tourism perspective, on-going growth in demand for coastal tourism and investment in hazardous coastal locations, alongside ownership models that increase local exposure (e.g. where local operators operate a franchise of a global brand but are responsible for the risk management of all assets) are likely to exacerbate hazards (Mahon et al. 2013; Honey and Krantz 2007).

\section{Vulnerability to disasters and risk reduction measures}

A wide range of definitions and conceptual models exist for vulnerability, reflecting different schools, ontologies and research traditions (Hufschmidt, 2011, Gaillard 2010; Fuchs et al, 2012). In the hazard literature, vulnerability is the extent to which a community, system or asset is susceptible to the damaging effects of a hazard (UNISDR, 2012). Despite differences between conceptualisations, it is agreed that vulnerability is a multi-faceted concept that comprises many dimensions (Comfort et al. 1999; Fuchs et al. 2012). For example, the social structures of island populations and economies, level of awareness and knowledge of natural hazards, the destination's planning processes and policy environments, and investment into risk management are all important factors influencing vulnerability (e.g. Cutter et al. 2008; Le Masson and Kelman 2011; Thomalla et al. 2006; Wisner et al. 2004). Environmental drivers, such as global climate change, and unsustainable tourism practices (Graci and Dodds, 2010) that result in ecosystem degradation or resource overuse also increase vulnerability to hazards. 
Tourism has been found to be vulnerable to natural hazards because of businesses' lack of preparedness and knowledge, inadequate place-based hazard and vulnerability assessments (Le Masson and Kelmann 2011), and tourism's limited integration with national disaster management systems (Hystad and Keller 2008; Faulkner 2001). In a review of best practice in hazard management in the Caribbean, Simpson and Gladin (2008) note that incentives may be required to promote good practice in DRR amongst tourism operators. This may require interventions by the public sector, especially in an environment where developers prefer to invest in projects that have already proven to be successful elsewhere, thus avoiding innovative and resilient forms of tourism development (Honey and Krantz 2007). The broader literature documents a range of measures implemented by individual stakeholders to manage and reduce disaster risk (e.g. Burby and Wagner 1996; UNEP and CAST 2008) and increase adaptive capacity (Hufschmidt 2011). More recently, the focus has shifted from one of reactive response measures to a more comprehensive, participatory and proactive disaster planning (Innocenti and Albrito 2011; Daly et al. 2010; Wisner 2009). More specifically, it is now recognised that effective DRR needs to invest into disaster prevention and preparedness, alongside response, and also benefits from proactive recovery planning, resulting in the so-called Prevention, Preparedness, Response, and Recovery (PPRR) Framework of the Disaster Management Cycle (Cutter, 2003). The PPRR approach is in line with Hufschmidt's (2011) pre- and post-disaster phases of adaptation and Faulkner's Tourism Disaster Management Framework (2001) and has been 'tested' in the context of tourism (Becken and Hughey 2013). Although the PPRR has been criticised for the implied clear delineation between the phases in a disaster (Crondstedt 2002), we consider that it remains a useful way of categorising different types of measures. It is arguable that the PPRR approach represents a particular 'dominant' paradigm (the 'hazard' or 'behavioural' paradigm) that ignores underlying (political) causes of vulnerability, such as poverty and 
gender, and that it positions disasters as extraordinary events rather than part of normality of the marginalised in society (Smith 2004; Gaillard and Mercer 2012). However, in using PPRR as a means to categorise types of measures that can be taken, we do not ignore structuralist or political ecological paradigms of vulnerability. We see techniques, such as community-based risk reduction, livelihoods analyses and the use of participatory approaches (e.g., Mercer 2010, Gaillard 2010; Chambers 1995; Daly et al. 2010) as using measures that can be categorised using PPRR. Planning and poverty reduction programmes are themselves part of preparedness, whether community based bottom-up or driven by a top-down process.

\section{Proposed framework}

There is no comprehensive disaster risk reduction framework specific for tourism that integrates all of the factors introduced above, especially when focusing on natural hazards as well as impacts from future climate change (Kelman and Khan 2013). Clearly, a framework needs to comprise the interaction of natural hazards with human vulnerability factors, in the broader context of external and local changes of the physical and human environment (Hewitt 1997), including local, national and global disaster policy frameworks (Comfort et al. 1999). While a large number of vulnerability models exist (for a review and comparison of six models see Hufschmidt 2011), Turner et al.'s (2003) Vulnerability Framework serves as a suitable basis for developing the Tourism Disaster Vulnerability Framework (TDVF). Turner et al.'s framework builds on progress in sustainability science (blending hazard and climate change research), and can be usefully modified by borrowing from other vulnerability frameworks to better match the DRR focus. Key characteristics of Turner et al.'s framework are: i) the linkages between the place-based system in question and its wider human and physical environment, ii) particular hazards that stem from the cross-scale processes and conditions, iii) the vulnerability elements of the place-based system itself, including inherent sensitivities, coping mechanisms and planned responses to impacts, and iv) particular 
inclusion of dynamic changes in the external and internal environments. Different types of linkages and dynamics characterise both the specific human-environment system and its global context.

The TDVF conceptualises a tourist destination as a human-environment system, which is nested within the wider global and regional environment (Figure 1). A tourist destination (i.e. the "element at risk", Hufschmidt 2011) includes all organisations (both public and private sector), individuals (e.g. local people and tourists), communities, infrastructure, and environments that are involved more or less directly in tourism as a socio-economic activity. A destination can be as small as one particular (outer) island. Using such a place- and peoplebased interpretation of vulnerability is more in line with natural hazards research than with climate change research where vulnerability is often seen as systemic to larger areas such as a nation (Wisner 2009). At destinations, hazards result as an interaction of changes in human and environmental conditions. These in turn are influenced by larger-scale global drivers, for example climate change, and the political environments in which they occur and develop (Comfort et al 1999). As in Turner et al.'s original framework, the hazards sit partly within the system of the tourist destination and partly external to it. Hazards interact with the destination's inherent vulnerability; the results of this interaction can be interpreted as risks and impacts. Vulnerability is composed of social, economic and environmental dimensions (Moreno and Becken 2009). All systems have some inherent coping mechanisms (as indicated in Turner et al.'s framework), but there is also a need to proactively develop measures that help to reduce vulnerability, address barriers to effective DRR, and reduce hazards. All of these are visualised with reverse arrows. While Turner et al. refer to such actions as adjustment and adaptation responses, in line with the terminology commonly applied in climate change research, we propose to employ the DRR typology of prevention, preparedness, response and recovery prevalent in emergency management. 
Effective DRR at a particular destination may also impact positively on external trends, visualised by an arrow from the tourist destination to the global and regional environment. The TDVF has been simplified somewhat from the original framework, and a number of elements and linkages are not shown (e.g. an explicit distinction into exposure and sensitivity). The omission does not deny their importance but is a result of focusing this present analysis on processes that can be evaluated empirically within the scope of this research.

FIGURE 1 ABOUT HERE

\section{Methodology}

To validate the TDVF, empirical data were collected from three regions where popular island tourist destinations are found, namely: 1) the Caribbean, 2) the Pacific, and 3) the Indian Ocean (see also Méheux et al 2007). While there are considerable differences between these regions, and among individual destinations within the regions, the islands are all characterised by high levels of tourism with a particular focus on beach-based tourism. All of the destinations considered in this research display a high exposure to a range of natural hazards, most notably tropical storms, flooding, and tsunamis (see also Table 1).

Due to the exploratory nature of this research it was important to develop a research design that generates a very broad range of perspectives and insights, and that also allows participants to express their views, concerns, and experiences in a relatively unconstrained format. A qualitative research approach using in-situ interviews was used to facilitate collection of information (Creswell 2009). While the research is inductive in that themes emerged during data collection, the research was guided by the general assumptions of the Tourism Disaster Vulnerability Framework, namely the existence of a hazardscape, vulnerability factors, and response measures; all of which influence each other. 
Empirical material was collected in mid-2011 (Caribbean) and mid-2012 (South Pacific and Maldives) by means of semi-structured face-to-face and telephone interviews. The schedule included both general and more specific questions that captured practitioners' experience with hazards and disasters in island destinations. National and regional level stakeholders in the public and private sectors were selected based on their professional positions (e.g. Chief Executives of tourism organisations), as well as using the referral technique of snowball sampling (Babbie 1989; Singleton, Straits and Straits 1993). Representatives of regional or international organisations were asked about their views on the particular island where they were based, but also on the broader region. Disaster management experts and industry practitioners (e.g., resort owners/managers) were interviewed on their views relating to the natural hazards that affect them most frequently, including their past experience with damage and loss associated with these natural hazards, and the measures taken to deal with future hazards and reduce disaster risk. To further 'tease out' potential vulnerability factors, without asking explicitly about vulnerability (as this is a technical term not necessarily utilised by tourism stakeholders), further questions on barriers and incentives to DRR were asked. In addition, two questions on the current policy environment and future policy needs to effectively deal with natural hazards were posed.

Altogether, 73 interviews were conducted with various tourism or disaster management stakeholders (Table 2). Interviews were in the English language, with the exception of four interviews in the Maldives which were undertaken in the local language Dhivehi. These were translated and transcribed by a bi-lingual researcher. All interviews were audio recorded and additional notes were taken during the interview to capture the interviewers' thoughts. The material from the transcripts and notes was coded to identify key themes. Direct quotes are used in the analysis to provide an impression of the 'original voice' and to underpin specific 
points. Respondents remain anonymous, but where useful and appropriate, organisations are identified.

TABLE 2 ABOUT HERE

\section{Results}

Hazards - environmental and human conditions

The interviews revealed a wide range of natural hazards that stakeholders are aware of, or have personally experienced in their respective island destinations (Table 3). The common denominator for all destinations is severe weather systems such as tropical storms, strong winds and flooding. One engineer from Fiji, who works closely with the tourism sector, noted: "... when you talk Fiji, you talk hazards and engineering...normally $90 \%$ of the time, we're talking...cyclones". Respondents from all destinations reported concerns about water shortages and drought, but these were often highly localised depending on the particular island's geography. For example, drought was a concern in relation to Vava'u in Tonga, but not reported in Tongatapu, the main island.

TABLE 3 ABOUT HERE

Climate change was mentioned as an important environmental factor that increases the hazard exposure of tourism in island destinations. A representative from an international organisation based in Samoa commented, "I think pretty much every climate change risk that affects coastal communities is affecting tourism [...] we all know that tourism is a microcosm of the environmental factors". In the case of the Maldives, perceptions of climate change 
were ambiguous, especially in relation to coastal erosion and inundation. Some research participants were of the view that erosion is a natural phenomenon ("we don't really consider it a natural hazard because it is a seasonal thing, it happens", representative of an international organisation in the Maldives) or caused by humans (e.g. due to the use of speedboats), while others emphasised the challenge that sea level rise constitutes for tourism and other sectors. Erosion is therefore a good example of how human (e.g. hard protective structures) and environmental factors (e.g. severe weather) interact to create local hazards (as depicted in the TDVF, Figure 1).

The hazardscape is perceived by research participants to be influenced by changes in socioeconomic conditions and business practices that stem from more general trends, external to the particular tourist destination. For example, one engineer in Fiji made the connections between the competing need for the built environment to be culturally Fijian in appearance, the use of particular materials to achieve market driven aesthetical goals, and the resulting sub-standard quality of the physical resilience of accommodation buildings: "Timber shingles in my opinion while they look good but you're just asking for trouble when the next cyclone comes along...". Another example of human factors driving exposure to hazards comes from the Maldives, where a tourist resort manager pointed out that beaches are highly dynamic and that coastal erosion is a problem only because "we define an area as the beach, it's the building, it's the jetty, and it's the guest services area...". Thus, the global demand for beaches close to the resort magnifies the natural hazard, because it denies the natural dynamics of beach systems.

Changing conditions and challenges beyond the particular island destination, as indicated in Figure 1, were also identified as relevant. In the South Pacific, for example, stakeholders perceived that the region's efforts in disaster risk reduction are substantially compromised by the dispersed nature of the different nations and destinations, which makes travelling around 
the Pacific time-consuming and expensive. Further, island nations, especially in the Maldives and the South Pacific case studies, were believed to experience difficulties in accessing support for hazard-related projects; partly because they lack the resources and capacity to administer projects. The dependence of DRR activities on international support and finance was particularly evident in the South Pacific and the Maldives, but was also observed in the Caribbean. The lack of integration between disaster risk reduction and climate change adaptation initiatives was noted by several interviewees, although interviewees also reported on a number of regional or national level initiatives, both in the Caribbean and the Pacific that explicitly seek to integrate both DRR and CCA considerations. Tonga was discussed as one of the few countries where both are integrated into a holistic national policy framework.

\section{Vulnerability and Risks}

Vulnerability and associated risks are shaped by a range of factors that are common, in principal, across the island destinations examined in this research. Five key vulnerability drivers for tourism are summarised in Table 4.

\section{TABLE 4 ABOUT HERE}

The core product at all destinations examined in this research is beach tourism. A tourism official in Antigua and Barbuda commented, "it would be very, very difficult to move from the beach...because of the sheer size of the island and the natural resources that exist.... tourism basically exploits what's there". Thus, regardless of the hazards inherent in coastal areas, tourism, including core infrastructure such as airports, is firmly anchored around the narrow strips where the land meets the sea. Some research participants recognised the challenge associated with operating in such exposed locations: "One of the problems is that the way that coastal tourism has evolved ... has left no buffer area available...to deal with some of these vulnerabilities and the risks associated with these hazards" (industry 
representative from Barbados). Risks associated with an over-dependence on coastal tourism relate to potentially severe economic impacts following a natural disaster, for example a cyclone or hurricane that destroys both tourism assets and the natural environment. Tourists do not appear to be actively demanding that a hotel operate at a prescribed distance from the sea, or has any other particular safety precautions in place. The opposite seems to be the case, at least in the minds of some industry stakeholders: "This industry was born on people being able to sleep and roll out their bed and go and lie on beach chairs and enjoy themselves" (Caribbean respondent). Thus, the present situation of tourism operations close to the beach is a result of historic, and sometimes deficient, planning processes ("there are some properties throughout the Caribbean that are very close and probably should never have been built that close to the beaches", private sector interviewee), and on-going demand for this type of product. While tourists demand beach experiences, inadequate siting and coastal management may pose risks to tourist safety and the quality of tourist experience.

Several interviewees pointed to the lack of adequate legislation and the insufficient implementation of existing policies. This was particularly evident in the Maldives, where a government official commented "in the government we are very fond of attending conferences; but we don't accept or apply the recommendations. We are signatories to many, but we don't act on these policies". Further, one non-governmental interviewee in the Maldives elaborated “if you look at the Disaster Management Bill, it hasn't been endorsed, it has been in draft form since 2006. Can you believe since 2006? It has not passed the Parliament yet, it hasn't gone to the Parliament yet." The challenges of implementation and policing were also referred to in Fiji where industry self-regulation was seen as a viable option for improving disaster risk reduction: “...we can't police every tourism investor to doing what is best for Fiji and tourism" (Government interviewee). Addressing those 
legislator challenges would reduce the risks associated with high damage costs after a disaster and also reduce public sector liability and associated costs.

Probably the most critical vulnerability driver that emerged from the interviews is the lack of private sector interest and investment in disaster risk reduction. Limited awareness, knowledge and concern were observed in all studied regions, although those affected by the tsunami in Samoa and Tonga showed higher levels of concern. In the Caribbean, a participant from a non-governmental organisation stated "For the financial controller and the CEO in a property - my thing is to keep my rooms filled and if a disaster comes along then I deal with it... so ... it is on my mind but it's not the first thing on my mind". There was even evidence of some in the tourism sector consciously downplaying risks to safeguard a positive image of the destination, rather than one that inspires fear amongst tourists. This was particularly apparent in the Maldives, where one resort manager commented: "For example, if we make emergency evacuation plans and put a lot of posters in the guest's room. When they come for the first time, they say 'what is going on - are we safe in this place'?"

Tourism is generally seen as an economic activity ("businesses are mostly for profit making sometimes they are not really willing to go investing in mitigating climate change or hazards", public sector interviewee, Maldives), and uncertainty around probabilities of hazards and their impacts make investment decisions in relation to DRR difficult. Very limited information on investment costs and pay-back times is available and managers are not able to make a clear-cut business case (as opposed to investments into energy efficiency, for example) (Mahon et al. 2013). Not addressing disaster risks, however, may result in an increased burden on the public sector and civic society, thus creating an external cost from tourism to society. In some cases, more specific information, such as better warning systems, would assist operators in their preparedness. Other tourism-specific factors, such as high staff 
turn-over, operating in remote locations, and a perceived lack of interest in disaster measures by tourists, act as barriers to private sector engagement with risk reduction measures.

The interviews clearly contained reference to poor environmental management that exacerbates the vulnerability of tourism in island destinations. The representative of an international organisation in Samoa reported the great demand to build seawalls (probably in response to the 2009 tsunamis) to protect shorelines and properties, even though these are often poorly constructed and destroy the natural beach environments. In the Maldives, a common concern related to waste management and the pollution of marine ecosystems, which weakens their resilience to natural hazards. Again, insufficient implementation of policies, such as Environmental Impact Assessment requirements was noted, as well as lack of awareness or concern about environmental issues on the part of the local population. The risks associated with compromised ecosystems (e.g. a reduced carbon sequestration capacity of mangrove forests) are a good example of a cross-scale effect, where local conditions can have repercussions for the condition of the global environment.

\section{Risk reduction measures}

The risk reduction measures discussed in the interviews cover all four phases of PPRR. Prevention typically involves planning or standards (e.g. building standards to withstand strong winds). In Fiji, for example, development in the coastal zone above the high water mark is subject to town planning requirements and a $30 \mathrm{~m}$ setback distance is applied. Similarly, the Environmental Impact Assessment Act 2003 in Tonga requires environmental impact statements for any major projects, including tourism or recreational resorts, buildings or facilities. In determining an assessment the Minister for the Environment must consider whether the project will "result in the occurrence, or increase the chances of occurrence, of natural hazards such as soil erosion, flooding, tidal inundation, or hazardous substances" 
(Government of Tonga, 2003, p. 8). Such a process should reduce the vulnerability of new resorts that exceed the definitional thresholds.

Hazard reduction and disaster prevention was also considered in some private sector activities. For example, resort owners in Samoa began using traditional vegetation for the roofs of the fales (beach huts), but tying them on more securely. The idea was that if they were destroyed by an event they would be relatively easy to replace, but that the method of tying them would make it more difficult for them to be destroyed. Non-traditional metal roofing had proven extremely hazardous in the 2009 tsunami, severely injuring several tourists, and is now avoided in construction.

Disaster preparedness is pursued by both the private and public sectors. A Maldivian resort owner stated that they cannot prevent a tsunami, but "we can prepare our teams and be ready for such situations so that they can react or act on the situation and everybody is safe and it doesn't affect the business". In Fiji, the national disaster management agency reported that the organisation works closely with hotels to ensure that they have multi-hazard disaster management and contingency plans, including evacuation plans. The estimate given was that about $90 \%$ of hotels have such plans in place.

Public sector preparedness often relates to the provision of early warning systems. Fiji, for example, receives assistance from Australia and New Zealand to enhance existing warning systems with satellite technology and computer models that supply technical hazard information, including for severe weather events. The partnership established between the National Disaster Management Office and the two cell phone operators in Tonga had led to the establishment of a system to send an 'impending event' warning text to all-subscribers. One resort manager commented specifically on the value of this as it had meant a warning at 05.00 hours of an impending cyclone that had established itself overnight, in the period since the last weather forecasts before they had gone to bed. 
A number of tourism stakeholders have invested into systems that facilitate an effective response. Tourism Fiji, the national marketing agency, has developed a crisis section to the organisation's website that is dormant during times of normalcy but is activated and loaded onto the website's front page during a crisis. The website gives real time information and status updates on the tourism industry's response to a crisis or disaster event and is key in managing crisis communications for the destination.

A senior disaster management representative reported that for the western division of Nadi, there was a separate water main for the tourist destination that serves only the resorts in normal times and has priority restoration rights in times of disaster. Hotels also receive special consideration and priority in terms of disaster recovery with regards to electricity restoration. While such arrangements potentially fuel local conflict, they are likely to enhance the recovery of tourism. Comments about the greater resilience of tourist resorts compared with local communities, and their ability to invest in disaster risk reduction and recovery measures, were also made in the Maldives. Several interviewees discussed the importance of insurance and business continuity plans for a successful recovery, and new ways of insuring business against hazards (e.g. index insurance) are explored in the Maldives and the Caribbean. One South Pacific stakeholder commented on the lack of insurance in the South Pacific compared with the Caribbean.

\section{Discussion}

The need to better understand the vulnerability of tourism to natural hazards is obvious (Wisner 2009). Tourism is growing globally, and the demand for island tourism is on-going (UNWTO 2011). However, it is also well-established that islands are exposed to a wide range of hazards (Méheux et al 2007). Global trends of mounting pressures in coastal zones (e.g. from population growth and economic development) in combination with global 
environmental change are increasing the precariousness of human-environment systems in these geographic areas (Pelling and Uitto 2001). Since tourism is a core economic activity in many islands, and at the core of many people's livelihoods, the importance of reducing vulnerability and improving DRR for tourism is pertinent. Tourism's core relationship with critical infrastructure, such as coastal roads, airports, and cruise ship terminals, makes it even more pressing to identify ways of addressing vulnerabilities (Lewsey et al. 2004).

For these reasons, a Tourism Disaster Vulnerability Framework, based on Turner et al. (2003) and with input from other vulnerability models (Hufschmidt 2011), has been proposed and populated for a range of island destinations. Essential elements, such as the integrative nature of human and environmental factors and the cross-scale linkages and processes have been incorporated into the TDVF. Acknowledging the simplified and linear presentation in Figure 1 , the broad assumption underlying this research is that hazards are a combination of human and environmental factors that interact with a particular system in a particular place. The local system's vulnerability influences the type and magnitude of risks that result from these hazards and the disaster impacts, should an event occur. System-specific barriers may prevent the development of DRR measures; however, the successful implementation of prevention, preparedness, response, and recovery measures has a positive impact on the underlying vulnerabilities and the hazardscape itself (Becken and Hughey 2013). More explicit consideration of DRR in tourism should occur from the business level right up to national tourism organisations (Tsai et al. 2012).

Seventy-three interviews across destinations in the Caribbean, the South Pacific and the Indian Ocean were undertaken to gather information on stakeholders' perspectives on typical hazards, vulnerability drives and response mechanisms. The hazards reported were in line with the relevant literature (e.g. Becken 2005; Pelling and Uitto 2001), although both the interview data and previously published studies seem to focus somewhat more on the 
environmental dimensions of hazards, rather than the human ones. For example, research participants readily identified the existence of storms or tsunamis as potential or experienced hazards, but - with some exceptions - they referred less commonly to underlying development trends that interact with these hazards. It was often difficult to distinguish 'external' changes in human conditions (as shown in Figure 1) from 'internal' vulnerabilities. For example, the global trend of tourism growth and the popularity of beach-based products, including so-called over-water bungalows, have to be interpreted as factors that exacerbate hazards. However, the local response to this trend, namely the construction of new resorts and facilities in hazardous areas, clearly increases the vulnerability of the sector. The difference between externally human-enforced hazards and system-intrinsic vulnerability is probably academic in nature, but nevertheless useful when seeking to analyse cross-scale dynamics that drive disaster risks at a tourist destination.

The research identified important vulnerability drivers within the human-environment systems of the different destinations studied. These fully reflected the proposed dimensions of social (e.g. tourist demand and safety), economic (e.g. dependence on tourism, private sector investment), and environmental drivers (e.g. insufficient waste management), as shown in the TDVF. However, another type of vulnerability was identified in all three regions; political vulnerability (see also Hufschmidt 2011). The lack of political will, insufficient capacity, conflict and corruption, poor implementation and unstable political environments (e.g. in the Maldives and Fiji) were clearly driving tourism's vulnerability. This political vulnerability had important flow-on impacts on other vulnerability drivers. For example poor environmental planning, legislation and policing reportedly resulted in deteriorating ecosystems that consequently lost their ecosystem service functions. Lack of awareness or sense of urgency amongst public sector officials is likely to also influence levels of awareness amongst the population, including tourism businesses (Johnston et al. 2007). 
Thus, vulnerability often results from a lack of measures put in place (as also reported by Burby and Wagner 1996, in their early study on hazard management in New Orleans), which means that overcoming barriers to address disaster risk is essential. Barriers were identified for both the public and the private sector, and different approaches are required to address them. For example, where tourist operators or resort managers were aware of risks, such as the potential for facility-threatening erosion during storms, there was often a lack of specific scientific knowledge of the local biophysical systems to enable an effective response and a lack of resources to fund the necessary data gathering and analysis. Other barriers for private sector investment into DRR were located externally to the tourist destination (a link not shown in Figure 1 for reasons of simplicity). Local operators are to some extent restricted in their local decision making due to the international nature of tourism and the substitutability of destinations.

Often, local businesses operate in conjunction with international developers, investors and chains, and their decision making is largely driven by directives from outside the place. It has been argued in the literature, that the arrangements are sometimes designed to transfer risk from the overseas owners to the local operators (Honey and Krantz, 2007), thus increasing local vulnerability. However, elsewhere Burby and Wagner (1996) found that large internationally connected hotels are more prepared compared with individual locally owned businesses. Responses in this study indicated that larger resorts who operate as part of a global chain had invested more into DRR than small businesses, especially community owned operations, such as beach fales in Samoa. The influence of international links and business size on DRR activities deserves further research.

Notwithstanding a range of barriers, many businesses, tourism organisations, and government agencies engage proactively in DRR. The findings indicate that the public sector, often with support from international organisations, is often concerned with preventive measures and 
those that enhance preparedness. The private sector seems to focus more on preparedness and response, and possibly under-estimates in some cases the opportunities of prevention and the necessities of recovery planning. In fact, one resort owner in Samoa commented on the lack of fairness associated with a disbursement of recovery grants to small operators affected by the tsunami who were un- or under-insured. Larger businesses, like his own, who carried some level of insurance did not receive any assistance, even though they also suffered complete destruction. Thus, recovery may rely too much on public sector initiatives, and in fact international donations and aid projects.

While this research has evaluated the TDVF across seven tourist destinations, it is important to recognise that a detailed analysis of each destination is likely to reveal quite different factors and processes that determine tourism's vulnerability. Thus, the idiosyncrasies of a tourist destination drive its particular hazardscape, vulnerability make-up, and opportunities for DRR measures. In fact, it was very clear that the 2009 tsunami dominated hazard perceptions in Samoa and Tonga, whereas hurricanes and cyclones, respectively, were the most discussed hazard in the Caribbean and Fiji, and coastal erosion in the Maldives. The vulnerability in the Maldives was particularly influenced by the challenging political conditions, whereas Samoan interviewees, for example, reflected positively on their Government and recent initiatives. Interviewees in the Caribbean pointed to challenges associated with mass tourism and dense coastal development close to the beach; a point that was not made to this extent in the other regions that operate quite different tourism models. It would be important to further investigate the differences between the studied destinations, in particular by taking into account Turner et al.'s (2003, p. 8077) suggestions for future vulnerability analyses. These include, amongst others, to give particular consideration to the "complexity, interconnectedness, and iterative nature of the components" in a humanenvironment system, the "nested scales", and "critical interactions [...] that suggest response 
opportunities for decision makers". Such an extended analysis might also include the role that tourists play in demanding and consuming coastal tourism products, for example tourists' demand for destinations that have recently suffered a natural disaster (Rittichainuwat 2008) or the use of DRR investment as a marketing tool (Rittichainuwat 2013), and tourists' perceptions of risk related to hazards (Villegas et al. 2013).

\section{Conclusion}

This research responds to the need to address the causal factors that underlie tourism disaster risks in a context of continued growth in international tourism and the popularity of beach based tourism, especially in island destinations. Islands are known for their exposure to hazards, as well as their inherent socio-environmental vulnerabilities. To understand underlying drivers of disaster vulnerability, a Tourism Disaster Vulnerability Framework was developed. The conceptual model was then used to guide qualitative empirical research in three regions; the Caribbean, the South Pacific, and the Indian Ocean. The results highlight common, as well as idiosyncratic, factors that shape the islands' hazardscapes and vulnerabilities. Key vulnerability drivers covered social, economic, political and environmental dimensions. More specifically, Governments' (and national economies') dependence on beach tourism, coupled with on-going demand for beach-based products, were two key drivers of vulnerability. In addition, the lack of investment by industry into DRR was a major challenge. This lack is partly driven by lack of awareness, insufficient specialist knowledge, lack of resources, and an insufficient business case. Environmental degradation, caused both by tourism and other island activities, is another vulnerability driver. In addition to the dimensions identified in the proposed TDVF, an additional driver emerged; political vulnerability. Lack of adequate legislation, insufficient implementation, and unstable political 
environments are core factors that undermine DRR activities.

Despite a range of inherent vulnerabilities coupled with substantial barriers, the PreventionPreparedness-Response-Recovery model embedded in the TDVF yielded useful information on DRR activities undertaken. Both the public and private sector, as well as public-private sector partnerships, have demonstrated a range of proactive and innovative initiatives to reduce island tourism vulnerabilities and mitigate natural hazards. Considering that each destination differs from each other, mutual learnings could be highly beneficial. Future research might address how to best stimulate inter-island exchange of information and knowledge. Such local-global interactions would be in line with Turner et al.'s (2003) initial vulnerability framework on cross-scale dynamics.

\section{References}

Babbie ER (1989) The practice of social research. $5^{\text {th }}$ Edition. Belmont, Wadswort

Becken S (2005) Harmonising climate change adaptation and mitigation: The case of tourist resorts in Fiji. Global Environmental Change, 15(4): 381-393

Becken S (2012) Visitor Sector Response to the Christchurch Earthquake. Ministry of Economic Development, Wellington

Becken S (2013). Developing a Framework for Assessing Resilience of Tourism SubSystems to Climatic Factors. Annals of Tourism Research, http://dx.doi.org/10.1016/j.annals.2013.06.002

Becken S and J Hay (2012) Climate Change and Tourism: from Policy to Practice. Routledge, London 
Becken S and K Hughey (2013) Tourism and natural disaster risk reduction - Opportunities for integration. Tourism Management, 36: 77-85

Becken S, Hay J and S Espiner (2011) The risk of climate change for tourism in the Maldives. In Butler, R. and Carlsen, J. (eds). Island Tourism Development. Journeys towards Sustainability. CABI, Oxford, Wallingford, UK

Bird DK, Gisladottir G, and D Dominey-Howes (2010) Volcanic risk and tourism in southern Iceland: Implications for hazard, risk and emergency response education and training. Journal of Volcanology and Geothermal Research, 189(1-2): 33-48

Burby RJ and F Wagner (1996) Protecting tourists from Death and Injury in Coastal Storms. Disasters, 20(1): 49-60

Calgaro E and K Lloyd (2008) Sun, sea, sand and tsunami: examining disaster vulnerability in the tourism community of Khao Lak, Thailand. Singapore Journal of Tropical Geography, 29(3): 288-306

Chambers R (1995) Poverty and livelihoods: whose reality counts? Environment and Urbanization, 7(1): 173-204

Climate Commission (2011) The Critical Decade. Climate Science, Risks and Responses. Climate Commission Secretariat, Department of Climate Change and Energy Efficiency, Commonwealth of Australia, Canberra, Australia, 72pp.

Comfort L, Wisner B, Cutter S, Pulwarty R, Hewitt K, Oliver-Smith A, Wiener J, Fordham M, Peacock W and F Krimgold (1999) Reframing disaster policy: the global evolution of vulnerable communities. Global Environmental Change Part B: Environmental Hazards, 1(1): 39-44

Creswell JW (2009) Research Design. Qualitative, Quantitative and Mixed Methods Approaches. $3^{\text {rd }}$ Edition. Sage Publications, Thousand Oaks 
Crondstedt M (2002) Prevention, preparedness, response, recovery - an outdated concept? Australian Journal of Emergency Management, 17(2): 10-13

Cutter S (2003) GI Science, Disasters, and Emergency Management. Transactions in GIS, 7(4): 439-445

Cutter S L, Barnes L, Berry M, Burton C, Evans E, Tate E and J Webb (2008) A place based model for understanding community resilience to natural disasters. Global Environmental Change, 18: 598-606

Daly M, Poutasi N, Nelson F and J Kohlhase (2010) Reducing the climate vulnerability of coastal communities in Samoa. Journal of International Development, 22: 265-281

Faulkner B (2001) Towards a framework for tourism disaster management. Tourism Management, 22: 135-147

Fuchs S, Birkmann J and T Glade (2012) Vulnerability assessment in natural hazard and risk analysis: current approaches and future challenges. Natural Hazards, 64: 169-1975

Gallard J C (2010) Vulnerability, capacity and resilience: perspectives for climate and development policy. Journal of International Development, 22:218-232

Gaillard J C and J Mercer (2012) From knowledge to action: bridging gaps in disaster risk reduction. Progress in Human Geography, 37(1): 93-114.

Government of Tonga (2003) Environmental Impact Assessment Act 2003. Available at (1/02/13) http://legislation.to/Tonga/DATA/PRIN/2003016/EnvironmentalImpactAssessmentAct2003.pdf

Graci S and R Dodds (2010) Sustainable tourism in island destinations. Earthscan, London, Washington, DC

Hein L, Metzger M and A Moreno (2009) Potential impacts of climate change on tourism; a case study for Spain. Current Opinion in Environmental Sustainability, 1: 170-178 
Hewitt K (1997) Regions of risk: a geographical introduction to disasters. Addison Weesley Longman, Harlow

Honey M and D Krantz (2007) Global Trends in Coastal Tourism. Prepared for Marine Program World Wildlife Fund, Washington, DC. Available at (14/05/2012)

Hufschmidt G (2011) A comparative analysis of several vulnerability concepts. Natural Hazards, 58: 621-643

Hystad PW and PC Keller (2008) Towards a destination tourism disaster management framework: Long-term lessons from a forest fire disaster. Tourism Management, 29: $151-162$

Innocenti D and P Albrito (2011) Reducing the risks posed by natural hazards and climate change: the need for a participatory dialogue between the scientific community and policymakers. Environmental Science and Policy, 14(7): 730-733

Intergovernmental Panel on Climate Change (2012) Summary for Policy Makers, Special Report on Managing the Risks of Extreme Events and Disasters to Advance Climate Change Adaptation (SREX). Available at (20/11/2011) http://ipcc-wg2.gov/SREX Intergovernmental Panel on Climate Change (2007) Fourth Assessment Report (AR4). Summary for Policymakers. Synthesis Report. Available at (20/03/2011) http://www.ipcc.ch/publications_and_data/publications_ipcc_fourth_assessment_repo rt_synthesis_report.htm

Johnston D, Becker J, Gregg C, Houghton B, Paton D, Leonard G and L Garside (2007) Developing warning and disaster response capacity in the tourism sector in coastal Washington, USA. Disaster Prevention and Management, 16(2): 210-216

Kellens W, Neutens T, Deckers P, Reyns J and P Maeyer (2012) Coastal flood risks and seasonal tourism: analysing the effects of tourism dynamics on casualty calculations. Natural Hazards, 60:1211-1229 
Kelman I and Khan K. (2013) Progressive climate change and disasters: island perspectives. Natural Hazards, DOI 10.1007/s11069-013-0721-z

Knutson TR, McBride JL, Chan C, Emanuel K, Holland G, Landsea C, Held I, Kossin JP, Srivastava AK and M Sugi (2010) Tropical cyclones and climate change. Nature Geoscience, 3: 157-163

Le Masson V and I Kelman (2011) Disaster risk reduction on sovereign islands: La Réunion and Mayotte, France. Natural Hazards, 56: 251-273

Lewis J (1982) Natural disaster mitigation: Environmental approaches in Tonga and Algeria. The Environmentalist, 2: 233-246

Lewsey C, Cid G and E Kruse (2004) Assessing climate change impacts on coastal infrastructure in the Eastern Caribbean. Marine Policy, 28: 393-409

Mahon, R., Becken, S., \& Rennie, H. (2013) Evaluating the Business Case for Investment in the Resilience of the Tourism Sector of Small Island Developing States. A Background Paper Contributing to the Global Assessment Report on Disaster Risk Reduction (GAR) 2013. LEaP Research Report No. 32. Christchurch: Lincoln University.

Mäntyniemi P (2012) An analysis of seismic risk from a tourism point of view. Disasters, 36(3): 465-476

Méheux K, Dominey-Howes D, Lloyd K (2007) Natural hazard impacts in small island developing states: a review of current knowledge and future research needs. Natural Hazards 40:429-446

Mercer J (2010) Disaster risk reduction or climate change adaptation: are we reinventing the wheel? Journal of International Development, 22: 247-261

Moreno A and S Becken (2009) A Climate Change Vulnerability Assessment Methodology for Coastal Tourism. Journal of Sustainable Tourism, 17(4): 473-488 
Pelling M and J Uitto (2001) Small island developing states: natural disaster vulnerability and global change. Environmental Hazards, 3: 49-62

Rittichainuwat BN (2008) Responding to Disaster: Thai and Scandinavian Tourists' Motivation to Visit Phuket, Thailand. Journal of Travel Research, 46(4): 422-432

Rittichainuwat BN (2013) Tourists' and tourism suppliers' perceptions toward crisis management on tsunami. Tourism Management, 34: 112-121

Shakeela A, Ruhanen L and N Breakey (2012) Human Resource Policies: Striving for Sustainable Tourism Outcomes in the Maldives? Tourism Recreation Research, 2(37): $113-122$

Simpson M C and E Gladin (2008) Good Practices: Natural Hazard Risk Management in the Caribbean Tourism Sector. European Commission and Caribbean Tourism Organization

Singleton RA, Straits BC and MM Straits (1993) Approaches to social research. $2^{\text {nd }}$ Edition. Oxford University Press, New York

Smith K (2004) Environmental Hazards : Assessing Risk and Reducing Disaster, Fourth Edition. Routledge, London

Sovacool B (2011) Perceptions of climate change risks and resilient island planning in the Maldives. Mitigation and Adaptation Strategies for Global Change, 17(7): 731-752.

Thomalla F, Downing T, Spanger-Siegfried E, Han G and J Rockstroem (2006) Reducing hazard vulnerability: towards a common approach between disaster risk reduction and climate adaptation. Disasters, 30(1): 39-48

Tsai H, Tseng C, Tzeng S, Wu T and J Day (2012) The impacts of natural hazards on Taiwan's tourism industry. Natural Hazards, 62:83-91 
Turner B L, Kasperson R E, Matson PA, McCarthy JJ, Corell RW, Christensen L, Eckley N, Kasperson J, Luers A, Martello ML, Polsky C, Pusipher A and A Schiller (2003) A framework for vulnerability analysis in sustainability science. Proceedings of the National Academy of Sciences of the United States of America, 100(14): 8074-8079

UNEP and CAST (2008) Disaster Risk Management for Coastal Tourism Destinations.

Responding to Climate Change. A Practical Guide for Decision Makers. UNEP DTIE:

Paris. Available at $(08 / 11 / 2012)$

http://www.unep.fr/scp/publications/details.asp?id=DTI/1048/PA

UNISDR (2012) ‘Terminology’. Available at (29/11/2012)

http://www.unisdr.org/we/inform/terminology\#letter-v

UNWTO (2011) Tourism Highlights. 2011 Edition. Available at (12/05/2012)

http://mkt.unwto.org/sites/all/files/docpdf/unwtohighlights11enlr_3.pdf

Villegas J, Matyas C, Srinivasan S, Cahyanto I, Thapa B and L Pennington-Gray (2013)

Cognitive and affective responses of Florida tourists after exposure to hurricane warning messages. Natural Hazards, 66:97-116

Wisner B (2009) Vulnerability. International Encyclopedia of Human Geography, 2009: 176182

Wisner B, Blaikie P, Cannon T and I Davis (2004) At Risk: Natural Hazards, People's Vulnerability, and Disasters. $2^{\text {nd }}$ Edition. London: Routledge

World Tourism Organisation and World Meteorological Organisation (1998) Handbook on Natural Disaster Reduction in Tourist Areas. WTO, Madrid

World Bank (2006) Not if But When: adapting to natural hazards in the Pacific Islands Region. The World Bank, Sydney 
WTTC (2011) Travel and Tourism's Economic Impact: Caribbean. Retrieved from

http://www.tourismiskey.com/downloads/2011/WTTC_Tourism2011.pdf

Table 1 Examples of damage and loss due to disaster in island destinations (Source: after Mahon et al., 2013)

\begin{tabular}{|c|c|c|}
\hline Country & Event & Damage and loss \\
\hline Jamaica & $\begin{array}{l}\text { Hurricane } \\
\text { Gilbert (1988) }\end{array}$ & $\begin{array}{l}\text { Damage to property and equipment amounted to US } \$ 85 \text { million; } \\
\text { Indirect damage was much greater; Foreign exchange losses from } \\
\text { tourism during September-December } 1988 \text { were US } \$ 90 \text { million. }\end{array}$ \\
\hline $\begin{array}{l}\text { Antigua } \\
\text { and } \\
\text { Barbuda }\end{array}$ & $\begin{array}{l}\text { Hurricane Luis } \\
\text { (1995) }\end{array}$ & $\begin{array}{l}\text { Estimated damage in excess of US\$ } 270 \text { million equivalent to } 71 \% \text { of } \\
\text { the island's GDP and } 83 \% \text { of the GDP from tourism. }\end{array}$ \\
\hline $\begin{array}{l}\text { Trinidad } \\
\text { and } \\
\text { Tobago }\end{array}$ & $\begin{array}{l}\text { Hurricane Ivan } \\
\text { (2004) }\end{array}$ & $\begin{array}{l}\text { Some disruption to telephone and electricity supply; loss of roofing } \\
\text { to houses; one local death. }\end{array}$ \\
\hline Fiji & $\begin{array}{l}\text { Nadi Floods } \\
(2009)\end{array}$ & $\begin{array}{l}\text { Businesses affected by salt water flooding of premises and associated } \\
\text { problems (e.g. blocked pipes); Denarau island was cut off as a result } \\
\text { of flooded roads; one set of four hotels are estimated to have lost a } \\
\text { combined value of US } \$ 1.7 \text { million from the cancellation of two } \\
\text { international conferences. }\end{array}$ \\
\hline Samoa & $\begin{array}{l}\text { Tsunami } \\
(2009)\end{array}$ & $\begin{array}{l}\text { Twenty villages on Upolu' south side were reportedly destroyed, and } \\
\text { about } 80 \text { people lost their lives, including a small number of tourists. } \\
\text { Several of the } 59 \text { tourist resorts operating on this coast were } \\
\text { destroyed by waves up to } 8 \mathrm{~m} \text { high. }\end{array}$ \\
\hline Tonga & $\begin{array}{l}\text { Tsunami } \\
(2009)\end{array}$ & $\begin{array}{l}\text { Nine lives lost in Niuatoputapu and } 90 \% \text { of residences destroyed in } \\
\text { two districts. }\end{array}$ \\
\hline Maldives & $\begin{array}{l}\text { Tsunami } \\
(2004)\end{array}$ & $\begin{array}{l}\text { Substantial damage and flooding of several islands. Three fatalities } \\
\text { and a number of foreign tourists seriously injured. } 21 \text { of the } \\
\text { country's } 87 \text { resorts sustained considerable damage and were closed. } \\
\text { Airport closed for } 24 \text { hours. }\end{array}$ \\
\hline
\end{tabular}


Table 2 Interviews undertaken for this study

\begin{tabular}{|c|c|c|c|c|c|}
\hline Region & Countries & Public sector & $\begin{array}{l}\text { Private } \\
\text { sector }\end{array}$ & $\begin{array}{l}\text { Other } \\
\text { organisation }\end{array}$ & Total \\
\hline \multirow[t]{4}{*}{ Caribbean } & Regional & 2 & 1 & $5^{*}$ & 8 \\
\hline & Trinidad and Tobago & 2 & 5 & 1 & 8 \\
\hline & Antigua and Barbuda & $2 *$ & 8 & & 10 \\
\hline & Jamaica & & 4 & 1 & 5 \\
\hline \multirow[t]{3}{*}{ Pacific } & Fiji & 2 & 7 & 4 & 13 \\
\hline & Samoa & 3 & $3 *$ & 3 & 9 \\
\hline & Tonga & 2 & 6 & & 8 \\
\hline AIMS & The Maldives & 5 & 4 & 3 & 12 \\
\hline TOTAL & & & & & 73 \\
\hline
\end{tabular}

* One interview by phone. 
Table 3 The range of hazards reported by research participants

\begin{tabular}{ll}
\hline Destinations & Range of hazards \\
\hline $\begin{array}{l}\text { Caribbean: } \\
\begin{array}{l}\text { Antigua and } \\
\text { Barbuda, }\end{array}\end{array}$ & $\begin{array}{l}\text { Tropical storms and hurricanes; Coastal erosion; Storm surge; Coastal } \\
\text { flooding; Drought; Earthquakes; Landslips; Tsunamis; Sea level rise; }\end{array}$ \\
$\begin{array}{l}\text { Jamaica, } \\
\text { Trinidad and } \\
\text { Tobago }\end{array}$ & $\begin{array}{l}\text { High near shore temperatures; Coral bleaching; Harmful algal blooms; Dirt } \\
\text { and othe pollution; and Jellyfish }\end{array}$ \\
$\begin{array}{l}\text { Pacific: } \\
\begin{array}{l}\text { Fiji, Samoa, } \\
\text { Tonga }\end{array}\end{array}$ & $\begin{array}{l}\text { Cyclones; Tsunamis; Coastal erosion; Storm surge; Flooding; Drought; } \\
\text { Earthquakes; Landslips; and Sea level rise }\end{array}$ \\
Maldives & $\begin{array}{l}\text { Flooding; Tsunamis; High air temperatures; Coral bleaching; Severe } \\
\text { weather; Drought; Coastal erosion; Loss of biodiversity; Climate variability; } \\
\text { and Disease (dengue fever) }\end{array}$ \\
\hline
\end{tabular}




\begin{tabular}{ll}
\hline Vulnerability Driver & Risks \\
\hline $\begin{array}{l}\text { Islands' high dependence on coastal } \\
\text { tourism }\end{array}$ & $\begin{array}{l}\text { Reduction in tourist arrivals and reduced economic } \\
\text { contribution, increased unemployment and decreased } \\
\text { regional development. }\end{array}$ \\
$\begin{array}{l}\text { High tourist demand for a coastal } \\
\text { product }\end{array}$ & $\begin{array}{l}\text { Unsatisfactory tourist experience and limited repeat } \\
\text { visitation. Compromised health and safety risk for } \\
\text { tourists staying close to the beach. }\end{array}$ \\
$\begin{array}{l}\text { Deficient planning and coastal } \\
\text { development, and lack of } \\
\text { implementation of legislation }\end{array}$ & $\begin{array}{l}\text { Damage to buildings, infrastructure and } \\
\text { environmental assets. }\end{array}$ \\
$\begin{array}{l}\text { Financial costs to businesses and/or insurance } \\
\text { companies. } \\
\text { Public sector liability and costs. }\end{array}$ \\
$\begin{array}{l}\text { Lack of private sector resources to } \\
\text { effectively implement DRR }\end{array}$ & $\begin{array}{l}\text { High costs to businesses in case of a disaster; } \\
\text { implications for business viability and reputation. } \\
\text { Unsustainable burden on the public sector and civic } \\
\text { society. }\end{array}$ \\
\hline $\begin{array}{l}\text { Loss and degradation of coastal } \\
\text { ecosystems }\end{array}$ & $\begin{array}{l}\text { Losses of biodiversity and environmental assets (e.g. } \\
\text { coral and fish species). } \\
\text { Compromised provision of ecosystem services (e.g. } \\
\text { protective function of mangroves and reefs). }\end{array}$ \\
\hline
\end{tabular}




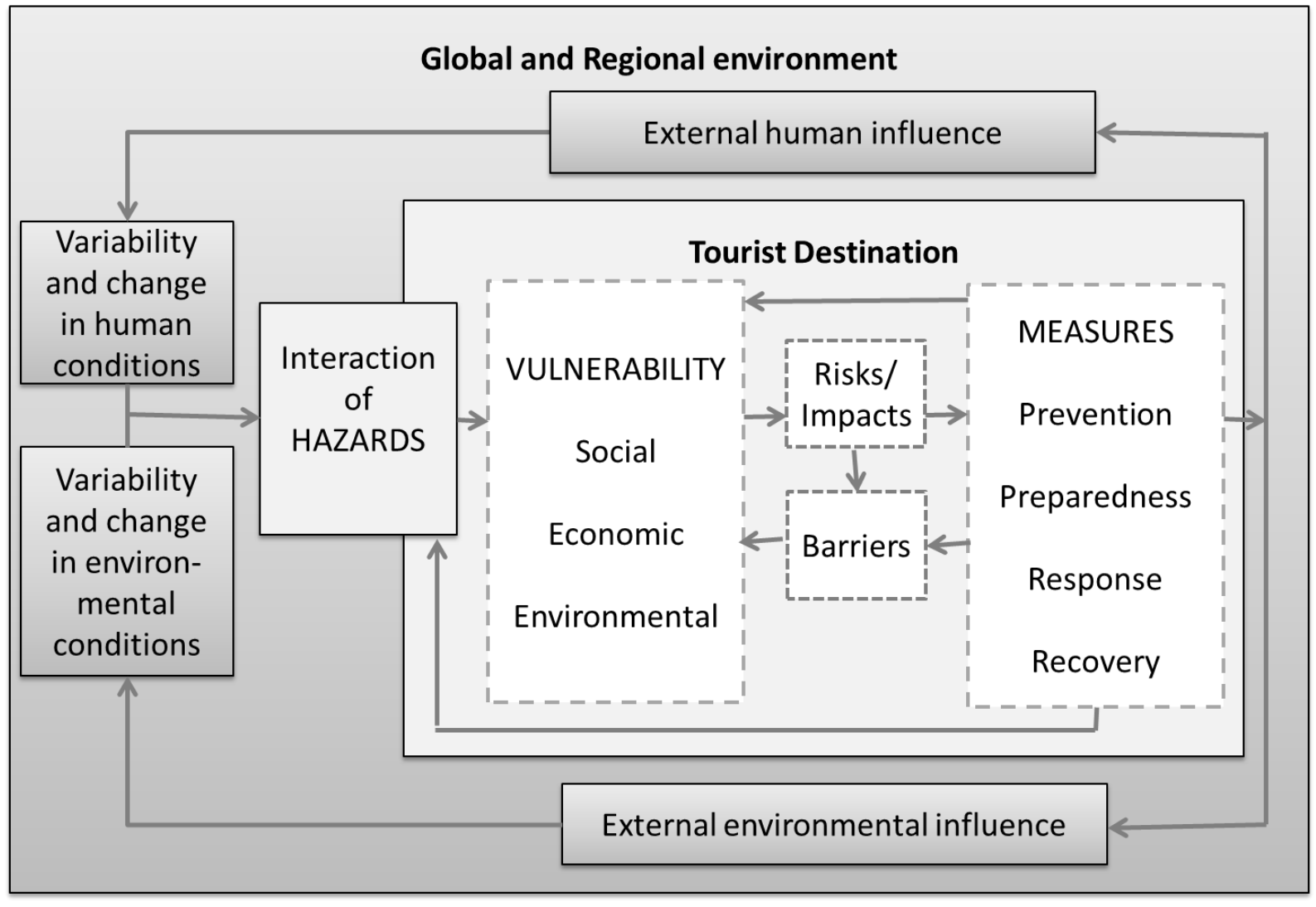

Figure 1 The Tourism Disaster Vulnerability Framework used in this research. 